\title{
SPECYFIKA ZARZĄDZANIA KAPITAŁEM INTELEKTUALNYM W FIRMACH RODZINNYCH
}

Z a r y s t r e ś c i: We współczesnych organizacjach coraz większego znaczenia nabierają zasoby niematerialne, wśród których ważne miejsce zajmuje szeroko rozumiany kapitał intelektualny. Kapitał, który odpowiednio zarządzany przyczynia się do osiągnięcia przewagi konkurencyjnej. $\mathrm{W}$ opracowaniu przeanalizowano wybrane aspekty zarządzania kapitałem ludzkim, relacyjnym i strukturalnym w świetle literatury oraz przeprowadzonych badań wśród firm rodzinnych. Dokonano próby wykazania specyfiki firm rodzinnych w aspekcie poszczególnych elementów kapitału intelektualnego.

S ł o w a k 1 u c z o w e: firma rodzinna; kapitał intelektualny; kapitał ludzki; kapitał relacyjny; kapitał strukturalny.

K 1 a s y fik a c j a JE L: L21.

\section{WSTĘP}

Złożoność otoczenia rynkowego wzmaga konkurencję i skłania przedsiębiorstwa do poszukiwania przewag nad innymi firmami. W działaniach tych coraz większego znaczenia nabiera podmiotowa orientacja na ludzi

* Adres do korespondencji: Paula Pypłacz, Politechnika Częstochowska, Wydział Zarządzania, Instytut Informacyjnych Systemów Zarządzania, ul. Armii Krajowej 19b, 42-200 Częstochowa, e-mail: paula@zim.pcz.pl; Katarzyna Peter-Bombik, Uniwersytet Jagielloński, Wydział Zarządzania i Komunikacji Społecznej, Instytut Spraw Publicznych, ul. Łojasiewicza 4, Kraków, e-mail: k.peter-bombik@uj.edu.pl. 
ukazana w aspekcie zarządzania zasobami ludzkimi, potencjałem ludzkim oraz szeroko rozumianym kapitałem intelektualnym przedsiębiorstwa. Waga kapitału intelektualnego jest coraz większa przede wszystkim jako elementu, który ma podnieść wzrost wartości firmy. Klasyczne zasoby (kapitałowe, techniczno-technologiczne, materialne) są ciągle istotne, ale coraz rzadziej stanowią obszary, w których można szukać szans na szybki rozwój przedsiębiorstwa. Tak więc prawdziwa wartość przedsiębiorstwa tkwi w jej niematerialnych zasobach, a budowa trwałej przewagi konkurencyjnej w zakresie zarządzania kapitałem intelektualnym wymaga realizacji szeregu działań poprzez kreowanie przyjaznej atmosfery sprzyjającej pogłębianiu i wymianie wiedzy, opracowanie efektywnych systemów motywacyjnych, budowanie trwałych relacji z interesariuszami, wpływanie na zaangażowanie pracowników w wykonywane zadania i ponoszenie odpowiedzialności za nie czy też wdrażanie rozwiązań informatycznych ułatwiających codzienną pracę.

Firmy rodzinne to specyficzny rodzaj przedsiębiorstw, których cechy powodują, że w pewnych kwestiach mogą osiągać przewagę nad przedsiębiorstwami nierodzinnymi. Tak właśnie jest z kapitałem intelektualnym, co jest wynikiem pozytywnego familizmu. Są to bowiem firmy, w których odpowiednie proporcje między rodziną i biznesem pozwalają na tworzenie odpowiednio silnej kultury organizacyjnej, zaufania i ładu organizacyjnego.

Celem opracowania jest przybliżenie istniejących w literaturze rozważań na temat istoty kapitału intelektualnego z uwzględnieniem jego poszczególnych elementów składowych w aspekcie wykorzystania go szczególnie przez małe i średnie firmy rodzinne. W opracowaniu przedstawione zostaną także wyniki badań ankietowych przeprowadzonych wśród 142 firm rodzinnych prowadzących działalność w różnych branżach. Badane firmy należą do sektora MSP. Badania ankietowe przeprowadzono w IV kwartale 2014 roku i I kwartale 2015 roku za pomocą elektronicznych formularzy, jak i osobistych wizyt w firmach. W badaniu udział wzięli zarówno pracownicy firm, jak i właściciele (kadra zarządzająca).

\section{KAPITAŁ INTELEKTUALNY W FIRMIE RODZINNEJ}

Kapitał intelektualny odgrywa coraz większą rolę z uwagi na wzrost znaczenia niematerialnych aktywów w kapitale przedsiębiorstwa - stanowi część całkowitej wartości przedsiębiorstwa i jest różnicą między rynkową a księgową wartością przedsiębiorstwa [Pietruszka - Ortyl, 2004, s. 12]. 
Jest on traktowany również jako źródło finansowania niematerialnych zasobów firmy przyczyniających się do generowania strumienia przyszłych korzyści, a więc wpływających na proces kreowania wartości firmy [Dobija, 2003, s. 10].

Wśród charakterystycznych jego właściwości wymienia się wspomnianą postać niematerialną, niemierzalną, niepoliczalną, niepodlegającą klasycznej ewidencji księgowej. Nie podlega też jednoznacznej wycenie. Ponadto bywa wykorzystywany do realizacji różnych celów, w wielu miejscach, a w trakcie wykorzystywania nie jest zużywany, lecz ma zdolność do samoistnego zwiększania swojej wartości [Skrzypek, 2009, s. 18].

W firmach rodzinnych szczególną rolę odgrywa właściciel, który najczęściej wybiera odpowiedni sposób zarządzania kapitałem intelektualnym. Zależy on od przyjętej koncepcji kapitału intelektualnego, całościowej strategii przedsiębiorstwa oraz uwarunkowań sytuacyjnych i czasowych. To właściciel realizuje funkcje inicjowania i inspirowania, dba o atmosferę i bezpieczeństwo pracy [Łobos, Pypłacz, 2015, s. 129, 130]. Ponadto to właśnie właściciel zatrudnia pracowników i wybiera dany styl zarządzania. Ważne by był tak dobrany i realizowany, by pogodzić interesy firmy oraz rodziny, co jest często problematyczne. Równocześnie należy dobrać odpowiedni zespół, zbudować odpowiednią strukturę organizacyjną, która pozwoli na elastyczność działań, ale również na poczucie stabilności. Zarządzanie kapitałem intelektualnym to także zachowanie odpowiednich relacji z otoczeniem. Relacji, które będą wpływały pozytywnie na wartość kapitału relacyjnego, a równocześnie będą na tyle hermetyczne, bo nie dopuszczały obcych wpływów.

Kapitał intelektualny w literaturze przedmiotu jest różnorako klasyfikowany. W niniejszym opracowaniu przyjęto jeden z częściej wymienianych podziałów, w którym dzieli się go na trzy składniki: kapitał ludzki, strukturalny i relacyjny. Na wartość kapitału intelektualnego niewątpliwie wpływają relacje (odpowiednio kształtowane) występujące pomiędzy tymi trzema składnikami.

\section{KAPITAŁ LUDZKI W FIRMIE RODZINNEJ}

Kapitał ludzki stanowi podstawowy element kapitału intelektualnego. To właśnie pracownicy z ich kompetencjami tworzą wartość firmy. Odpowiedni pracownik jest w stanie realizować działania i zaspokajać oczekiwania oraz potrzeby klientów. 
Jednym z ważniejszych aspektów kapitału intelektualnego są kompetencje pracowników, które obejmują wiedzę, doświadczenie i praktyczne umiejętności, wewnętrzną motywację, uzdolnienia i predyspozycje oraz inne cechy psychofizyczne istotne z punktu widzenia wykonywanej pracy, postawy i zachowania spodziewane $\mathrm{w}$ miejscu wykonywania pracy oraz formalne uprawnienia do działania. W literaturze przedmiotu można spotkać różne podziały kompetencji na odpowiednie kategorie. W odniesieniu do pracowników przedsiębiorstwa część oczekiwanych kompetencji jest wspólna dla ogółu podmiotów, natomiast część z nich jest wyraźnie odmienna. Stąd też można wyróżnić kompetencje uniwersalne oraz kompetencje specyficzne dla niektórych zawodów, specjalności czy stanowisk. Kompetencje te mogą również wynikać ze specyfiki rynku, na którym funkcjonuje dane przedsiębiorstwo, ale także jego produktów czy indywidualnych klientów. W firmach rodzinnych kompetencje pracownicze często nie pokrywają się z kompetencjami osobistymi, są postrzegane raczej przez pryzmat pracy zawodowej oraz stanowiska, na jakim został zatrudniony dany pracownik [Kulej-Dudek, Pypłacz, Smoląg, 2011, s. 183-198 ].

W toku przeprowadzonych badań dokonano próby wyszczególnienia kompetencji i umiejętności, które są najbardziej cenione przez pracodawców. Wg ankietowanych pracowników najważniejsze jest wykształcenie (69\% odpowiedzi) i doświadczenie (74\% odpowiedzi). Natomiast kadra zarządzająca oceniła, iż najważniejsze dla niej jest: chęć uczenia się (88\% odpowiedzi), samodzielność w podejmowaniu decyzji (47\%) i komunikatywność (42\% odpowiedzi). Można więc uznać, iż w praktyce gospodarczej firm rodzinnych nie istnieje zespół ,uniwersalnych kompetencji zawodowych". Należy określić pewien ich zestaw z szerokiego zbioru dobrze opracowanych kompetencji, a następnie wybrać te, które są najbardziej odpowiednie dla danego przedsiębiorstwa.

Jednym z ważniejszych elementów zarządzania kadrami - kapitałem ludzkim jest nabór pracowników do firmy rodzinnej. Kandydaci bardzo często poszukiwani są w kręgu osób z rodziny, potem wśród znajomych i na końcu wśród osób z zewnątrz. Jednak głównym kryterium winny być ich kompetencje, a nie ich przynależność do danej grupy. Szczególnie, że problematyczne staje się później zwalnianie osób niesprawdzających się na stanowisku pracy. Często, by nie powodować konfliktów rodzinnych, osobom takim tworzy się nowe stanowiska (często sztuczne), które ograniczają odpowiedzialność tych osób, a pozwalają uniknąć konfliktów rodzinnych związanych ze zwalnianiem. Działania takie mimo wszystko generują niepotrzebne, dodatkowe koszty. Optymistyczny jest fakt, iż w badanych 
firmach rodzinnych respondenci określili, iż podczas procesu doboru pracowników najczęściej bierze się pod uwagę kompetencje kandydata (57\% odpowiedzi), a dopiero w drugiej kolejności fakt, iż kandydat jest członkiem rodziny ( $45 \%$ odpowiedzi).

Kapitał ludzki to nie tylko wiedza pracowników. To także ich zaangażowanie, chęć rozwiązywania konfliktów, wprowadzania zmian, tworzenia przyjaznego środowiska pracy. Tym samym tworzenia organizacji całościowej - dbania i rozwijania kompetencji organizacyjnych. W badaniach pracownicy potwierdzili chęć wprowadzania zmian, uznali, że akceptują wprowadzane zmiany w zakresie działań kadrowych (całkowicie akceptuje $33 \%$ respondentów, częściowo akceptuje $37 \%$, sporadycznie - 20\%, a 10\% nie akceptuje). Ze strony kadry właścicielskiej i zarządzającej sytuacja wygląda podobnie. Określili, że $28 \%$ ich pracowników całkowicie akceptuje wprowadzane zmiany i postępuje zgodnie z nowymi wytycznymi. Natomiast uważają oni, że $18 \%$ pracowników nie akceptuje zmian i sprzeciwia się im. Pomocnym elementem może być silna kultura organizacyjna, która pozwala na wybór (czasem nawet intuicyjny) osób z podobnymi wartościami, poglądami, czyli ,pasujących” do rodzinnego modelu firmy, a tym samym takich osób, które będą sprzyjały nowościom i zmianom.

\section{KAPITAŁ STRUKTURALNY W FIRMIE RODZINNEJ}

Kolejną częścią kapitału intelektualnego jest kapitał strukturalny nazywany również kapitałem organizacyjnym. Kapitał strukturalny może być własnością przedsiębiorstwa i obejmuje sprzęt komputerowy, oprogramowanie, bazy danych, patenty, znaki handlowe, strukturę organizacyjną oraz wszystko to, co jest zdolnością przedsiębiorstwa i wspiera produktywność pracowników [Edvinsson, Malone, 2001, s. 45; Sasak 2009, s. 173]. Ma on istotne znaczenie w procesie kształtowania relacji ze względu na swoje zasoby w postaci własności intelektualnej (patenty, licencje, znaki towarowe itp.) oraz kapitału procesowego (procesy naboru kadr, produkcji, marketingowe, systemy IT) [Danielak, 2010, s. 256].

W przeprowadzonych badaniach zapytano czy pracownicy wspierani są rozwiązaniami informatycznymi i w jakim zakresie. Główny obszar wsparcia to programy finansowo-księgowe ( $80 \%$ odpowiedzi), prowadzenie baz danych klientów i dostawców (50\% odpowiedzi), możliwość uczestniczenia w szkoleniach e-learningowych - głównie zewnętrznych (34\% odpowiedzi). Niewiele firm natomiast posiada zintegrowane systemy 
informatyczne wspierające organizację całościowo (tylko 10\% odpowiedzi). Jak widać, wsparcie występuje głównie w standardowych obszarach, często wymaganych przepisami prawa czy wytycznymi firm współpracujących (np. systemy informatyczne odbiorców).

Niekorzystna sytuacja jest również w obszarze innowacji. Badane firmy niezbyt mocno inwestują $\mathrm{w}$ prace $\mathrm{B}+\mathrm{R}$ (tylko $12 \%$ respondentów prowadziło dotychczas takie prace), a tym samym nie wdrażają innowacji (tylko $10 \%$ wdrożyło w ciągu ostatnich dwóch lat). Jednak nie jest to typowy problem firm rodzinnych, ale ogólnie firm sektora MSP.

Ważnym elementem kapitału strukturalnego jest również kultura organizacyjna, która znajduje swój wyraz w procesie komunikacji czy w relacjach formalnych i nieformalnych. Większe podmioty mają wypracowane własne, utrwalone sposoby działania w zakresie kultury organizacyjnej, czego nie można powiedzieć o mniejszych firmach. Tam najczęściej kultura organizacyjna jest odzwierciedleniem postaw, przekonań i stylu zarządzania właściciela. Kultura organizacyjna przedsiębiorstwa rodzinnego jest jednym z głównych czynników wpływających na rozwój wartości integrujących rodzinę z firmą. Powinna równoważyć różne cele i wartości dwóch systemów: rodziny i przedsiębiorstwa i powodować ich wzajemne wspieranie się [Sułkowski, Marjański, 2011, s. 108]. Potwierdziły to badania, w których 79\% respondentów oceniło kulturę organizacyjną w ich firmie jako silną i proefektywnościową. Świadczy to o tym, że pracownicy popierają politykę prowadzoną w firmie, identyfikują się z firmą i czują się pewnie w strukturach, w których pracują.

W przedsiębiorstwach rodzinnych szczególnego znaczenie nabiera tożsamość - czyli to w jaki sposób pracownicy postrzegają swoją organizację, na ile się z nią identyfikują. W przypadku firm rodzinnych $\mathrm{z}$ jednej strony pracownicy $\mathrm{z}$ rodziny $\mathrm{z}$ zasady mają większe poczucie przynależności do firmy, a tym samym wpływają na spójność tej firmy, co jest niewątpliwą zaletą. Ale z drugiej strony problem może pojawić się wśród pracowników spoza firmy, którzy mogą czuć się wyobcowani, nie do końca związani z firmą poprzez brak przynależności do rodziny.

Tak więc, mimo iż wiele dzieli przedsiębiorstwa rodzinne, to niewątpliwie kultura organizacyjna oparta na familizmie jest elementem wspólnym łączącym je [Sułkowski, Marjański, 2011, s. 109]. 


\section{KAPITAŁ RELACYJNY W FIRMIE RODZINNEJ}

Kolejnym elementem kapitału intelektualnego jest kapitał relacyjny, który odnosi się do zasobów relacyjnych powstających z potencjału nagromadzonego w przedsiębiorstwie, czyli umiejętności, jakimi dysponują pracownicy, [Bąkowska-Morawska, 2008, s. 115] oraz do relacji zewnętrznych, jakie zachodzą między przedsiębiorstwem i podmiotami z jego otoczenia. Kapitał relacyjny obejmuje znajomość strategii konkurencji i uwarunkowań zewnętrznych, w tym sytuacji gospodarczej kraju i polityki rządu. Relacje nawiązywane są zarówno z interesariuszami wewnętrznymi, wśród których wymienić należy m.in. właścicieli przedsiębiorstw, kadrę zarządzającą, pracowników, związki zawodowe oraz zewnętrznymi, tj.: dostawcami, odbiorcami, dystrybutorami, klientami, konkurentami, instytucjami finansowymi, administracją państwową i samorządową, społecznościami lokalnymi, klastrami. Jak widać, relacji tych jest wiele, należy zaangażować cały zespół w kształtowanie korzystnych związków między przedsiębiorstwem i jego interesariuszami, gdyż sprzyja to osiąganiu korzyści przez każdą ze stron.

Kapitał relacyjny w firmach rodzinnych jest wyjątkowy. W środowisku, gdzie współdziałają członkowie rodziny relacje są silniejsze i stabilniejsze. Co nie oznacza, że nie brakuje konfliktów. Jednak te silne więzi wewnętrzne wpływają pozytywnie na relacje między firmą a klientami, społecznością lokalną i innymi interesariuszami. Składnikiem kapitału relacyjnego są wewnętrzne kanały komunikacyjne, które rozwijają członkowie rodziny w ramach spotkań rodzinnych, jak i podczas pracy. Kapitał relacyjny w firmie rodzinnej jest również kształtowany przez normy rodzinne, czyli zaufanie, zobowiązania, silną reputację. To właśnie normy rodzinne pozwalają koncentrować się na wartościach istotnych dla uczestników otoczenia zewnętrznego. Poza tym motywują, aby członkowie rodziny byli zaangażowani na rzecz dobra firmy oraz, by unikać konfliktów, które w firmach rodzinnych powstają najczęściej na płaszczyźnie właściciele - zarządzający.

W badaniach zapytano respondentów o relacje, jakie występują pomiędzy firmą a dostawcami, odbiorcami i konkurentami. Wszystkie typy relacji określane zostały na skali jako pozytywne/partnerskie. W przypadku powiązań z dostawcami pozytywne relacje przejawiają się głównie w terminowości dostaw oraz atrakcyjnych warunkach i terminach płatności. Odnośnie odbiorców to przede wszystkim usługi przy- i posprzedażowe oraz korzystne warunki serwisowe. Respondenci wskazywali również na budowanie zależności (z dostawcami, jak i odbiorcami) opartych na zaufa- 
niu i bezpieczeństwie. W przypadku konkurencji wskazywano na budowanie i utrzymywanie relacji współdziałania. Dążenie do relacji partnerskich i utrzymywanie ich można upatrywać w potrzebie poprawy konkurencyjności firmy. Relacje te mają przyczynić się w głównym stopniu do poprawy profesjonalizmu działań (64\% odpowiedzi), powiększenia skali działania (55\% odpowiedzi), co jest ważne przede wszystkim w przypadku małych i średnich firm. Rzadziej natomiast wskazywano, że relacje te przyczyniają się do wspólnego rozwiązywania problemów (17\% odpowiedzi).

W zakresie kapitału relacyjnego korzystna sytuacja jest w zakresie dzielenia się wiedzą między pracownikami ( $80 \%$ respondentów jest zadowolonych z tego jak procesy te są realizowane). Wprawdzie nie ma sformalizowanych programów i narzędzi do tego służących, ale wartości rodzinne, relacje między członkami rodziny, a także ich nieformalne spotkania i kontakty powodują że zarówno komunikacja, jak i procesy dzielenia się wiedzą są prowadzone na wysokim poziomie.

Słabo w badanych organizacjach prowadzone są działania w zakresie doskonalenia struktur organizacyjnych. Większość respondentów (87\%) nie zauważyło takich działań. Po analizie i wywiadach stwierdzono, że działania te jeśli są realizowane, to bez wiedzy pracowników. A, co więcej, wszelkiego rodzaju zmiany stanowiskowe i organizacyjne często nie kwalifikuje się jako typowa zmiana, a jako drobna modyfikacja, tak, aby nawet nie była zauważona.

\section{ZAKOŃCZENIE}

Całościowy proces zarządzania kapitałem intelektualnym w przedsiębiorstwie obejmuje wiele procesów, jak m.in. zapisywanie i przechowywanie przyjętej polityki w bazie danych, wzrost, odnawianie, szerzenie, ochronę oraz monitorowanie kapitału intelektualnego. Ocenia się, że odpowiednie zarządzanie wymienionymi procesami przynosi firmie wymierne efekty, które przyjmują postać: wzrostu wartości kapitału intelektualnego, możliwości eliminacji błędów, wzrostu innowacyjności, rozwoju zasobów intelektualnych, zarządzania wiedzą, wzrostu kreatywności i konkurencyjności pracowników, a w konsekwencji całych firm.

Kapitał intelektualny podlega procesom rozwojowym. Tylko stały rozwój zapewnia odpowiedni poziom elementów - składników kapitału i pozwala zachować przewagę w tym obszarze. Ważne jest współistnienie kultury organizacyjnej, tożsamości, odpowiednich, kompetentnych pra- 
cowników, infrastruktury informacyjnej i dobrych relacji pomiędzy firmą a interesariuszami wewnętrznymi i zewnętrznymi.

Mimo dostrzegania ważnej i strategicznej roli zarządzania kapitałem intelektualnym często brak praktycznych działań w małych firmach rodzinnych. Równocześnie wiele $\mathrm{z}$ tych działań realizowanych jest sporadycznie, jednorazowo. Brak długofalowej strategii w tym zakresie.

\section{LITERATURA}

Bąkowska-Morawska U., Elastyczność zasobów relacyjnych, w: Elastyczność organizacji, red. Krupski R., Wyd. UE we Wrocławiu, Wrocław 2008.

Danielak W., Elementy kapitału relacyjnego oddziałujące na konkurencyjność matych $i$ średnich przedsiębiorstw, w: Wyzwania i perspektywy zarzadzania w matych i średnich przedsiębiorstwach, red. Matejun M., Wyd. C.H. Beck, Warszawa 2010.

Dobija D., Pomiar i sprawozdawczość kapitalu intelektualnego przedsiębiorstwa, Wyd. Wyższej Szkoły Przedsiębiorczości i Zarządzania im. Leona Koźmińskiego, Warszawa 2003.

Edvinsson L., Malone M., Kapitat intelektualny, Wydawnictwo Naukowe PWN, Warszawa 2001.

Kulej-Dudek E., Pypłacz P., Smoląg K., Role and Importance of Selected Employee Competencies in the Aspect of Operation of SME, in: The Determinants of Entrepreneurship Development in SME Sector Companies, ed. Lachiewicz S., Szymańska K., Kurowska M., Technical University of Lodz Press, A Series of Monographs, Łódź 2011.

Łobos K., Pypłacz P., Funkcje i narzędzia zarzadzania dla małych i średnich przedsiębiorstw, Wyd. CeDeWu, Warszawa 2015.

Pietruszka-Ortyl A., Proces zarządzania kapitatem intelektualnym organizacji, „Przegląd Organizacji” 2004, nr 6.

Sasak J., Zarzadzanie przeptywem informacji jako warunek kreowania wiedzy w organizacji, w: Społeczne uwarunkowania sukcesu organizacji, red. M. Czerska, H. Czubasiewicz, Sopot 2009, Prace i materiały Wydziału Zarządzania Uniwersytetu Gdańskiego 2/9/2009, Wydział Zarządzania Uniwersytetu Gdańskiego.

Skrzypek E., Kapitat relacji jako element kapitału intelektualnego, w: Kapitał relacyjny w nowoczesnej gospodarce, red. Cisek M., Wyd. Studia Emka, Warszawa 2009.

Sułkowski Ł., Marjański A., Firmy rodzinne. Jak osiagnać sukces w sztafecie pokoleń, Wyd. Poltext, Warszawa 2011. 


\title{
SPECIFICS OF INTELLECTUAL CAPITAL MANAGEMENT IN FAMILY OWNED COMPANIES
}

\begin{abstract}
In the modern organizations the intangible assets such as intellectual capital are becoming more and more important. This capital, which properly managed, contributes to competitive advantages. The chosen aspects of human capital management, its relational and structural form in the light of literature and conducted surveys among family owned companies are analyzed in this paper. The specifics of family owned companies in the aspect of respective elements of intellectual capital are defined.
\end{abstract}

Keywords: family owned companies; intellectual capital; human capital; relational capital; structural capital. 